\title{
Why Can We Make Anything from Lignin Except Money? Towards a Broader Economic Perspective in Lignin Research
}

\author{
Julia Wenger $^{1} \cdot$ Verena Haas $^{1} \cdot$ Tobias Stern $^{1}$ \\ Accepted: 11 August 2020 / Published online: 29 October 2020 \\ (C) The Author(s) 2020
}

\begin{abstract}
Purpose of Review As a major component of wood, lignin is regarded as a promising, bio-based compound which could strongly influence the forest-based circular bioeconomy. Much research has been conducted on the material use of lignin, but the lignin commercialization process is still under development; few commercial production facilities and larger-scale applications are available. Therefore, we present a review of recent research papers on the economic perspectives on lignin.

Recent Findings Research has been conducted on lignin application areas such as lignin-derived polymeric materials, polymer and composite systems, applications for microsized and nanosized lignin, energy storage, and renewable chemicals. On the whole, the life cycle assessment results indicate that lignin-based innovations can be environmentally beneficial. Technoeconomic studies identified the lignin feedstock cost and the achievable product price as the most sensitive factors. Recently, researchers pointed out information asymmetries between different stakeholder groups concerning lignin-containing products. Summary Although most of the relevant papers presented a technical perspective of lignin, a smaller set of general economic statements about lignin appear in these papers. These statements refer to lignin underutilization, limited markets, resource abundancy, and barriers to utilization. The literature on technical lignin with an economic perspective can be divided into two different streams: several techno-economic papers and fewer socio-economic papers. The former placed a primary focus on production processes from a profit maximization perspective, but attempts were also made in the latter to explain the sociotechnical innovation system. To date, lignin researchers have focused mainly on internal (direct) factors but have not yet sufficiently considered external (indirect) factors.
\end{abstract}

Keywords Lignin sustainability · Lignin techno-economic $\cdot$ Lignin market · Lignin biorefinery $\cdot$ Lignin innovation . Cross-sectoral collaboration

This article is part of the Topical Collection on Forest Policy, Economics and Social Research

Electronic supplementary material The online version of this article (https://doi.org/10.1007/s40725-020-00126-3) contains supplementary material, which is available to authorized users.

Julia Wenger

julia.wenger@uni-graz.at

Verena Haas

verena.haas@uni-graz.at

Tobias Stern

tobias.stern@uni-graz.at

1 Institute of Systems Sciences, Innovation and Sustainability Research, University of Graz, Merangasse 18/I, 8010 Graz, Austria

\section{Introduction}

\section{Forest-Based Biorefinery Research and the Case of Lignin}

Lignocellulose is considered to be the most abundant terrestrial plant material [e.g., 1•]. In research papers dedicated to biorefinery development, this material amounts to approximately $60 \%$ of all feedstock mentioned [2]. Forest-based or wood biorefineries have the potential to provide a readily available feedstock, allowing for a relatively broad product portfolio [3]. These biorefineries reduce competition for food and feed as compared with most starch-, sugar-, and oil-based feedstocks and could contribute to the replacement of fossilbased resources to a certain extent [3].

In the context of the forest-based circular bioeconomy, lignin is considered as a key to commercial success, potentially 
representing between 24 and $47 \%$ of the current returns from pulp production [3]. Wood-pulping processes are usually developed and optimized for the generation of high-quality cellulose (cellulose makes up 40-50\% of wood), whereby current biorefinery operations are not geared towards the isolation and valorization of other major wood constituents such as hemicelluloses (25-35\% of wood) and lignin (18-35\% of wood) [4-6]. Hellsmark and Söderholm [7] suggested that biorefineries could serve as a platform to revitalize the mature pulp and paper industry [7], which is the major producer of technical lignin, such as Kraft lignin and lignosulfonates $[1 \bullet, 8]$. Pulping facilities around the world produce an estimated 40-50 million tons per year of this technical lignin [e.g., 8-11], which is currently mainly burnt on-site (about 95-98\%) to recover the process chemicals and obtain energy [e.g., 4, 9, 12]. However, a surplus of lignin is produced, especially due to improvements in the energy efficiency of pulp mills [e.g., 13, 14]. This surplus could enable value-added products to be produced from part of the generated technical lignin without affecting the required energy supply $[13,15,16 \bullet \cdot]$. Today, only a small amount (i.e., approximately $2 \%$ ) of the available lignin is isolated from spent pulping liquors and used commercially [e.g., 12, 17]. Despite the large quantities of technical lignin available from the dominant Kraft process, lignosulphonates are currently more strongly established on the market than lignin from black liquor [e.g., $16 \bullet \bullet$.

Lignin is regarded as a promising bio-based compound and is expected to play an important role in biorefinery design [3]. For example, it is generally considered as an underutilized side-stream and the major existing bio-based aromatic resource [18]. It has the potential to yield a wide variety of products, which are currently under investigation $[12,18$, 19]. Much research has been undertaken to identify the higher-value uses of lignin; nevertheless, the commercialization of lignin is still under development, with few commercial production facilities and larger-scale applications available [16••]. Accordingly, a common saying among representatives of the pulp and paper industries is "one can make anything from lignin except money" [18.; p. 716].

Therefore, we conducted a comprehensive review of lignin research and specifically identified papers in which an economic perspective was taken. The conclusions drawn from the synopsis of the reviewed papers help to contribute to a better overall understanding of lignin-related innovation systems. By identifying research gaps that still need to be filled, we describe some reasons why the commercialization of lignin still faces significant challenges and suggest ways these challenges can be met.

\section{General Approach and Structure of the Paper}

To achieve these research objectives, we applied a systematic approach. A detailed description of the approach taken, including the search terms and (number of) papers identified, can be found in the supplementary material (ESM 1).

Therewith, we identified relevant research papers and classified these within the following three topical domains in lignin research. The first domain contained papers (scientific articles and reviews) which have a focus on natural-science and technology-related aspects. These papers also contained, for instance, information on conceivable applications of lignin, general assumptions about its market potential, and market information and data from different (non-scientific) sources, such as commercial market reports and trade databases. The second domain encompassed papers in which a focus was placed on sustainability assessments (mainly regarding the environmental performance) and/or technoeconomic assessments (TEAs) of lignin. These studies were mostly based on certain process technologies and specific assumptions. The third domain included a smaller number of socio-economic papers in which drivers and barriers that are important from a more holistic perspective were addressed, e.g., related to external factors necessary for lignin-based products to be successful on the market.

This paper is structured as follows:

(1) In the section entitled "Current Research on Lignin: the Research Output, Considered Applications, and MarketRelated Aspects," we provide a short overview of the development of lignin research in recent years. Ten general and frequently occurring statements about the economic aspects of lignin were collected from papers and books (which were not based on market-based approaches) using a snowballing approach (see file ESM 1). This perspective on the use of lignin was complemented by highlighting current review papers that placed a primary focus on the possible future applications of lignin and certain papers that summarized market information from different non-scientific sources (these papers were selected with a systematic approach, see file ESM 1). Two figures are included in this chapter: Fig. 1 illustrates the increase in lignin research that has occurred in recent decades, and Fig. 2 displays the occurrence of selected, application-related search terms in the lignin literature.

(2) Next, in the section "Sustainability and TechnoEconomics in Lignin Research," we review the use of wood-based lignin for non-fuel applications from the perspectives of sustainability (mostly environmental impact assessments) and techno-economic assessments (TEAs). A summary of the approaches (nine sustainability assessments and ten TEAs), utilization pathways, and major findings is provided, including an overview table on the TEA papers.

(3) Then, in the section "Socio-Economic Assessments in Lignin Research," we focus on lignin commercialization 
from the product, consumer, and market perspectives. Relevant papers (a core of seven market-related papers) were identified (see file ESM 1). These papers were reviewed in detail to investigate the status quo in this branch of the scientific literature, to draw lessons from the major findings of these papers, and to identify research gaps. In this section, we provide a description of the investigated papers, an overview table, and a figure illustrating the socio-technical system, which includes the identified drivers of and barriers to lignin innovation diffusion.

(4) Finally, in the section "Conclusions and Discussion," we describe how an investigation of the identified research gaps may allow researchers to make a positive contribution towards a broader understanding of lignin commercialization on a larger scale. In addition, we discuss the findings in the context of the innovation literature, and, in particular, in the context of wood-based biorefineries and the forest-based circular bioeconomy.

\section{Current Research on Lignin: The Research Output, Considered Applications, and Market-Related Aspects}

The amount of research on the topic of lignin has strongly increased in recent decades, as illustrated in Fig. 1. Abejón et al. [20] carried out a bibliometric analysis on research trends concerning lignin valorization; for this purpose, they analyzed 353 papers published from 2000 to 2016 (using the Scopus database and searching for the terms "lignin" and "valorization" in the abstracts, titles, and keywords). They observed an exponential annual increase in the number of papers published on this topic (from six papers altogether before 2008 to 108 papers published in 2016). This positive trend has continued since then, with 322 papers published in 2019 using the same search string. The numbers of scientific lignin articles published, in general, and of lignin reviews (highest numbers in 2019: 1538 articles and 99 reviews) have also strongly increased over the last few years (Fig. 1). These papers mainly have addressed technology issues. The reviews provide concise summaries of various sub-topics, such as overviews of the most common sorts of technical lignin and their properties and/or their potential applications [e.g., 21-25]. Diverse valorization approaches are addressed in these reviews, which deal with the separation, modification (e.g., depolymerization), and/or upgrading of lignin [e.g., 1•, 4, 26-30], such as microbial lignin valorization [e.g., 31-35].

Most of the scientific literature on lignin presents research approaches in the fields of the natural sciences and technology, and little attention has been paid to lignin-based products and market aspects $\left[16 \bullet \cdot, 36^{\bullet}\right]$. Nonetheless, it is noticeable that probably due to the fact that much of this research could eventually lead to an economically advantageous use of ligningeneral statements about the economic relevance of lignin have often been made, for example, about its future potential. A rather small set of general statements on lignin applications and market aspects seems to have been made repeatedly, although references are often lacking for these stated assumptions. In the following section, the most commonly collected statements are summarized according to their meanings. They are listed in descending order by the frequency of mention (for detailed information on the frequencies of the statements and the reference list, see the supplementary material ESM 1):

- Lignin is a very abundant resource.

- Currently, the market for lignin is limited (heat and power, vanillin, lignosulphonates, niche markets).

- There is a barrier to lignin utilization, and lignin valorization is a challenge for several reasons.

- Further research and development/new processes could eventually enable the scalable production of lignin-based products: further research and development are needed.
Fig. 1 Number of papers about lignin published between 1990 and 2019 (Scopus database: lignin or lingnosul* in the title of a scientific article or review)

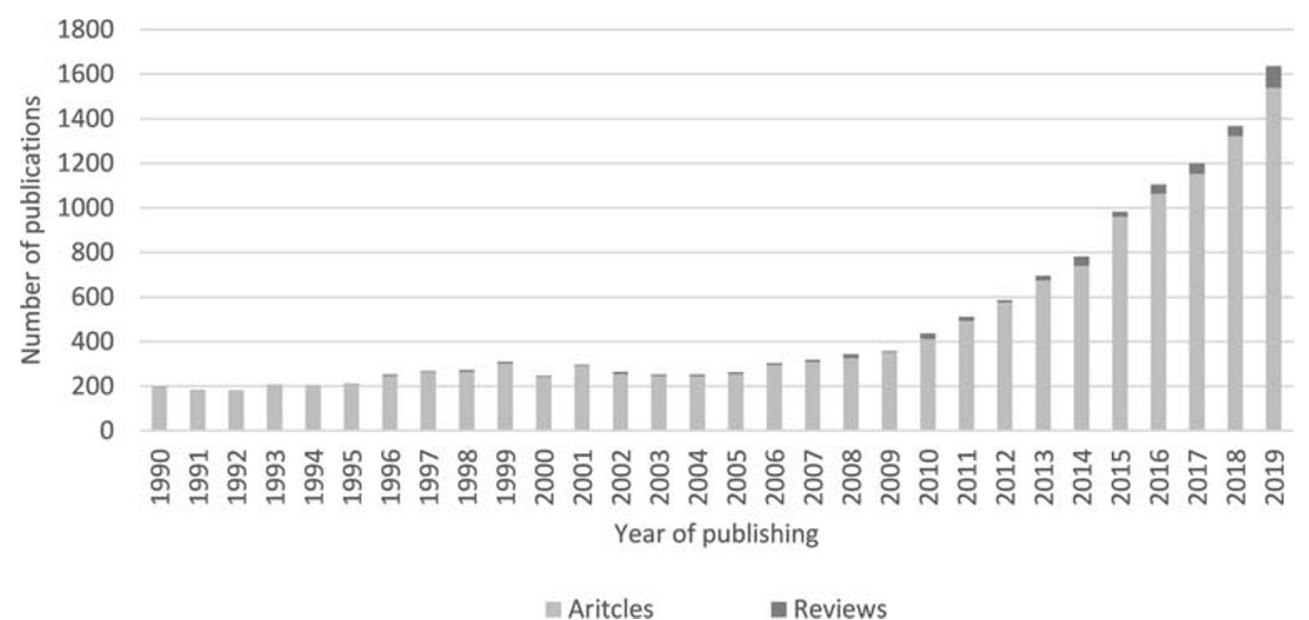




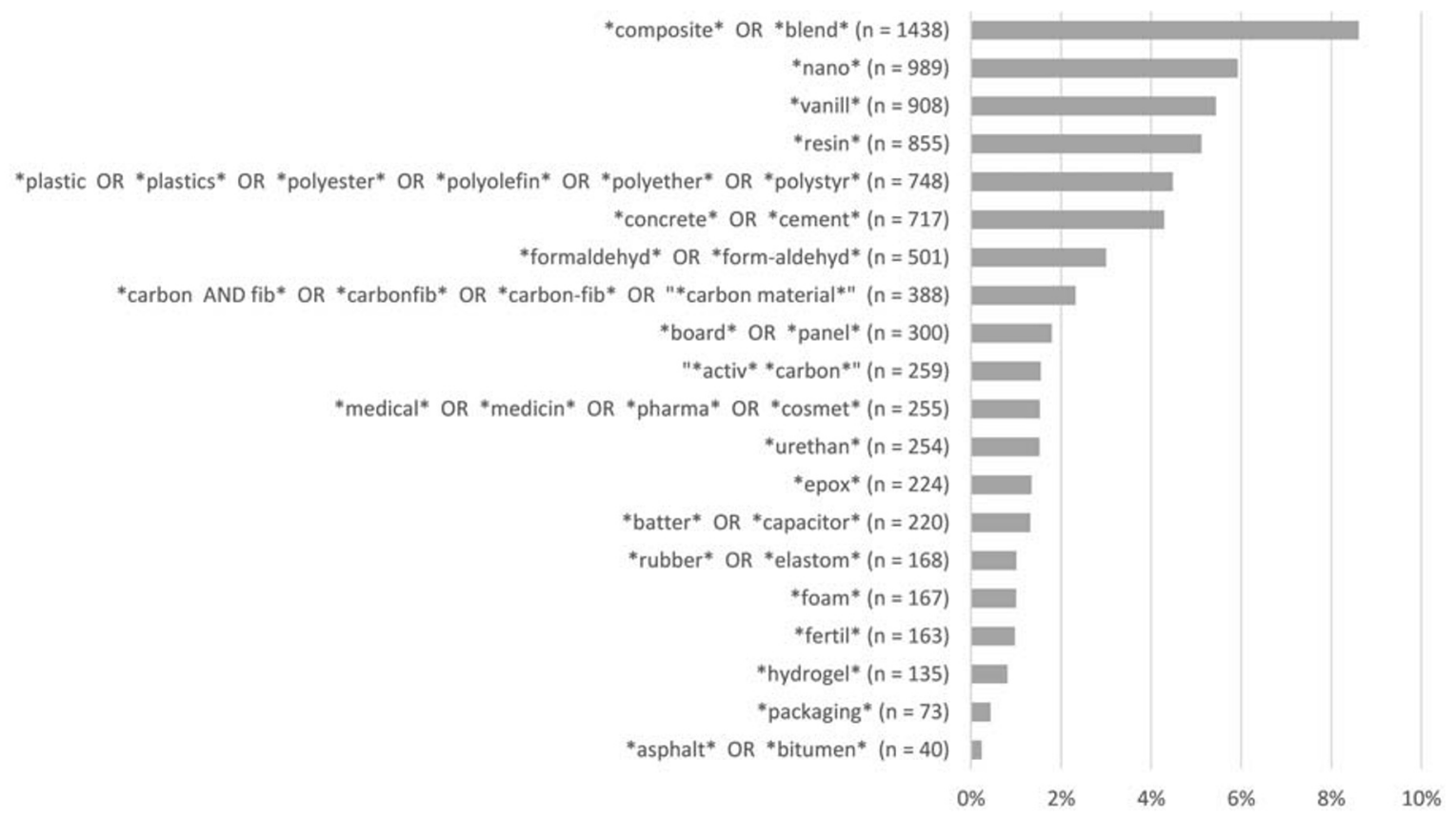

APPLICATION-RELATED SEARCH TERMS, ABSOLUTE FREQUENCY OF OCCURRENCE (NUMBER OF PAPERS), AND RELATIVE FREQUENCY OF OCCURRENCE (WITH REFERENCE TO THE LIGNIN DATASET, $\mathrm{N}=16,700$ ) TITLE (lignin OR lignosul*) AND TITLE-ABS-KEY (application-related search term) AND (LIMIT-TO(DOCTYPE, "ar")) AND (EXCLUDE (PUBYEAR, 2020))

Fig. 2 Search hits with selected, application-related search terms that occur in the titles, abstracts, or keywords of papers from a body of literature on the topic of lignin (Scopus database: lignin or lingnosul* in the title of scientific articles published up until 2019)

- Lignin is underutilized.

- Lignin plays a major role in biorefinery conception.

- The use of lignin for certain applications could reduce costs.

- Lignin is a sustainable, environmentally friendly material.

- Lignin is a promising material and has the potential to serve as an alternative to other materials.

- The amount of available lignin will increase.

\section{Applications Considered in Research}

A clear focus on the technology- and natural-science-related aspects of lignin was observed in the scientific literature. This has also been due to challenges associated with characteristics inherent to the (technical) lignin [e.g., 18, 23, 26]. These challenges, in turn, have driven research efforts to develop technology for biomass pretreatment and lignin separation to achieve an adequate quality, advanced chemical analyses to more precisely characterize lignin, and conversion approaches to create more valuable products [23].

Several reviews in recent years have addressed certain application areas [e.g., 8, 21, 37-39]. These areas include ligninderived polymeric materials [40-42], lignin in polymer and composite systems [8], applications for microsize and nanosize lignin $[25,43]$, lignin in storage and energy applications [44], lignin in food and/or pharmaceutical industries [24, 45], and lignin for renewable chemicals [28]. Li and
Takkellapati [1•] reviewed technical lignin sources, identifying valorization approaches and applications and focusing on their practical implementation. Figure 2 shows the relative frequency of occurrence of selected, application-related search terms in the literature on lignin (search conducted in titles, abstracts, and keywords; for more details see file ESM 1).

\section{Market-Related Aspects and Data Outlined in Research Papers}

With regard to the economic aspects related to these applications, little information is available in most of these papers. However, certain sources such as trade databases, market reports, and patents provide relevant information about lignin and its potential application fields. Information on markets (e.g., prices of products that are potentially replaced by lignin) have been collected and considered by several authors, either to review these aspects or to make valid assumptions as a basis for, e.g., techno-economic assessments.

Four review papers were identified that placed a strong focus on lignin markets and applications. Dessbesell et al. [16••] examined scientific peer-reviewed publications, supply and market publications, as well as patents on lignin. They provided detailed information on the global lignin market and supply, placing a special focus on phenols and polyols from Kraft lignin. The importance of these two application fields in the short- to mid-term was emphasized. The authors also recommended that only the Kraft lignin surplus, which is not 
needed as an energy source on-site, should be considered for chemical and material applications [16••]. Bajwa et al. [36•] described lignin sources and types, market volumes, and prices, as well as current and emerging applications, including market prices. They recommended the use of tools such as techno-economic assessments (TEAs) and life cycle assessments (LCAs) to identify the benefits and challenges of valorization pathways [36•]. Hodásová et al. [22] listed price ranges for several lignin types and for potentially replaced products. They focused on three groups of applications: (a) the use of depolymerized, aromatic compounds from lignin, (b) the use of lignin as a macromolecule, and (c) the use of carbon material from lignin. They concluded that lignin as a macromolecule is more highly developed than the applications of the other two groups, despite their higher market value. In particular, aromatic compounds from lignin were considered to have the greatest potential [22]. Graichen et al. [46] stated that lignin and other bio-based products could achieve market success, and they described some challenges that would need to be overcome to achieve this: (1) Capital and funding were identified as critical issues; (2) there is competition for biomass, and it needs to be available in sufficient quantity and quality; (3) the bioeconomy requires interdisciplinary and cross-sectoral communication and cooperation (new value chains); (4) innovations are often associated with high infrastructure costs; and (5) regulatory measures are strong drivers, but also unpredictable and often not fully understood by relevant stakeholders [46].

Brief overviews of market-related aspects were found in several papers. Lucid plots that illustrate market prices versus market volumes of potential applications were provided by Gabriel et al. [47] and, most recently, by Dessbesell et al. $[16 \bullet \cdot$. Prices and/or price ranges and production volumes for different lignin types were collected from different sources and were reported in several papers [e.g., 47, 48, 49•]. Prices and/or volumes of a range of potentially substituted products were also reported in several sources [e.g., 26, 47, 48, 50]. Companies and plants that already produce lignin and/or lignin-based products were mentioned in several papers. Detailed descriptions of these are provided in Dessbesell et al. [16••], Bajwa et al. [36•], and Li et al. [33]. The latter published overview tables on the key players on the lignin market, including the industrial lignin applications. Lignin patents were reviewed by Dessbesell et al. [16••], and lignin patents with applications in food and pharmaceutical industries were reviewed by Gil-Chávez et al. [24].

\section{Sustainability and Techno-Economics in Lignin Research}

The lack of available information on sustainability aspects in lignin research has been mentioned in several papers [e.g.,
36•, 44]. However, a small body of literature includes information on life cycle assessments (LCAs) and technoeconomic assessments (TEAs) related to lignin, some of which were reviewed by Bajwa et al. [36॰]. In the following section, we review selected LCA and TEA papers that were published in the last 5 years (2015-2019) and address woodbased lignin for non-fuel applications. Several assessments of uses for lignin from agricultural residues and/or uses of lignin for fuel applications are available [e.g., 49•, 50-58], but this topic was considered beyond the scope of this paper.

\section{Environmental Impact Assessments in Lignin Research}

The intended use of lignin for various applications is based on the premise that this undertaking would contribute to increased sustainability (in particular, the environmental performance of lignin-based products as compared with their current, often fossil-based counterparts). However, the broad spectrum of available ways to gain, valorize, and use lignin that are currently discussed in the scientific literature indicate that it is necessary to prove whether a considered option actually increases overall sustainability [36•]. For this reason, some authors have recommended supporting the product development with accompanying sustainability assessments, already starting during early research stages [59].

Several papers that described the use of such approaches with lignin were published recently. Bajwa et al. [36•] reviewed several LCA papers related to lignin and concluded that using tools such as LCA supports decision-making and allows users to select the most appropriate, lignin-based product design for future commercialization [36•]. A focus was placed on sustainability aspects of wood-based lignin for material or chemical applications in papers published on the following topics:

- An LCA of Organosolv lignin for tertbutyl catechol, and a comparison with the fossil-based counterpart [60]

- The impact of integrating a lignin extraction with LignoBoost in a softwood Kraft pulp mill for phenolformaldehyde (PF) adhesives [61]

- An LCA of a medium-density fiberboard (MDF) with a hybrid-modified ammonium lignosulfonate as binder, as compared with conventional MDF [62]

- The identification of environmental hotspots and sustainability levers of Kraft lignin valorization pathways for PF resins [59]

- The identification of an optimal process for using alkali lignin from Kraft pulping for vanillin production, using LCA and green design metrics [63]

- Environmental performance and "burdens shifting" resulting from pulp and bioethanol processes when a lignin fraction is removed; Kraft LignoBoost lignin for non- 
specified high value applications between 1000 and 2000 $€ / t[64]$

- The environmental performance of wood-based fiber laminates with hardwood Organosolv-lignin-based phenolic resins [65]

- A meta-LCA for screening purposes to analyze ligninbased and recycled carbon fibers in composites [66]

- A multi-regional input-output (MRIO)-based approach for analyzing the possible substitution impacts (environmental and socio-economic indicators) of using a part of the surplus lignin from the pulping industry in the chemicals sector, therewith substituting fossil-based resources [67]

On the whole, the results of these studies indicate that lignin-based innovations have the potential to be environmentally friendlier than current non-renewable alternatives regarding several impact categories, thus giving a positive outlook that lignin utilization could contribute to improved sustainability. This utilization refers primarily to environmental aspects, however, so significant research gaps may exist in terms of social aspects. The sustainability of lignin innovations should be assessed on a case-to-case basis, as the processes, approaches, and assumptions (e.g., the system boundaries and the allocation approaches used) are highly specific for each case and, therefore, can influence the outcome of such studies [e.g., 68, 69]. The sustainability-focused approaches also have the potential to reveal environmental hot-spots and to support decision-making for sustainable processes and products throughout the innovation process [e.g., 59].

\section{Techno-Economic Assessments in Lignin Research}

In Table 1, the TEAs conducted over the last 5 years (20152019) are summarized. These studies address the production and/or processing of forest-based lignin for non-energy applications: The feedstock (input for the lignin product), major processes considered, intended product, and/or application (including potentially substituted material), investigated country, and planned capacity of the biorefinery, as well as some major findings and conclusions are presented. Under the assumed conditions and scenarios, some approaches were found to be potentially economically feasible, while others were not considered as profitable at present (i.e., those applied to substitute phenol, for which the considered market price is too low). There are significant uncertainties regarding several assumptions made in these approaches, and varying these assumptions can yield different results. Therefore, the most commonly mentioned sensitive factors will be briefly described.

Almost every paper mentioned a major sensitive factor related to the cost of the lignin feedstock $[10,14,48,70$, 72-75], which could be crucial in determining the process feasibility. The second-most frequently mentioned sensitive factor concerned the market prices that can be obtained for the final product $[14,72-75]$. Plant capacity $[10,70,73]$ and, in particular, the increase in capacity represented factors that critically affected the profitability of a biorefinery. Other sensitive factors that were indicated included the costs for diverse input materials other than the lignin [14, 48, 75] and technology- and product-quality-related factors [e.g., 10, 71]. Given the high degree of uncertainty and sensitivity associated with lignin costs and prices, lignin products, and the market demand for these, the techno-economic assessments could be improved if investigations of the market environment are carried out to reduce such uncertainties.

\section{Socio-Economic Assessments in Lignin Research}

While several approaches exist to assess the environmental performance and techno-economics of lignin, few studies have been carried out to explore the possibilities associated with bringing value-added lignin products onto the market [9]. Other than the existing, rather specific papers on TEA and LCA, few papers present research approaches to investigate the market for or the sustainability of lignin in the broader sense of innovation systems. In the following section, these few papers are discussed in more detail and summarized in Table 2. Identified drivers and barriers that were considered to be relevant for the innovation diffusion of lignin and lignincontaining products are summarized in Fig. 3.

Hall et al. [76] described the so-called "Eroom" effect in combination with sustainable innovation, whereby lignin utilization (for vanillin and carbon fibers) represented one case study out of two. The phenomenon of improved priceperformance (Moore's law, Carlson curve) tends to be counteracted by the downstream costs for new technologies (e.g., for regulatory approval, labeling, and trade policies), which present particular challenges for public (e.g., universities) or smaller institutions. The authors concluded that labeling was a major issue in the case of Canadian lignin-based vanillin, and the use of carbon fibers was subject to major challenges regarding trade restriction policies and regulatory approval in the USA [76]. Lettner et al. [77] investigated factors that influence the market diffusion of bio-based plastics, whereby the feedstock lignin represented one case study out of four in the comparative case study approach. They concluded that the most viable scenario for increasing the substitution potential involves improving the properties and promoting technological innovation, thus contributing positively to the objective of increasing sales volume and reducing product price [77]. Lettner et al. [78••] analyzed the knowledge gaps (information asymmetries) between different stakeholder groups concerning Kraft-lignin based phenol-formaldehyde (PF) resins for wood-based panels and lignin-based 


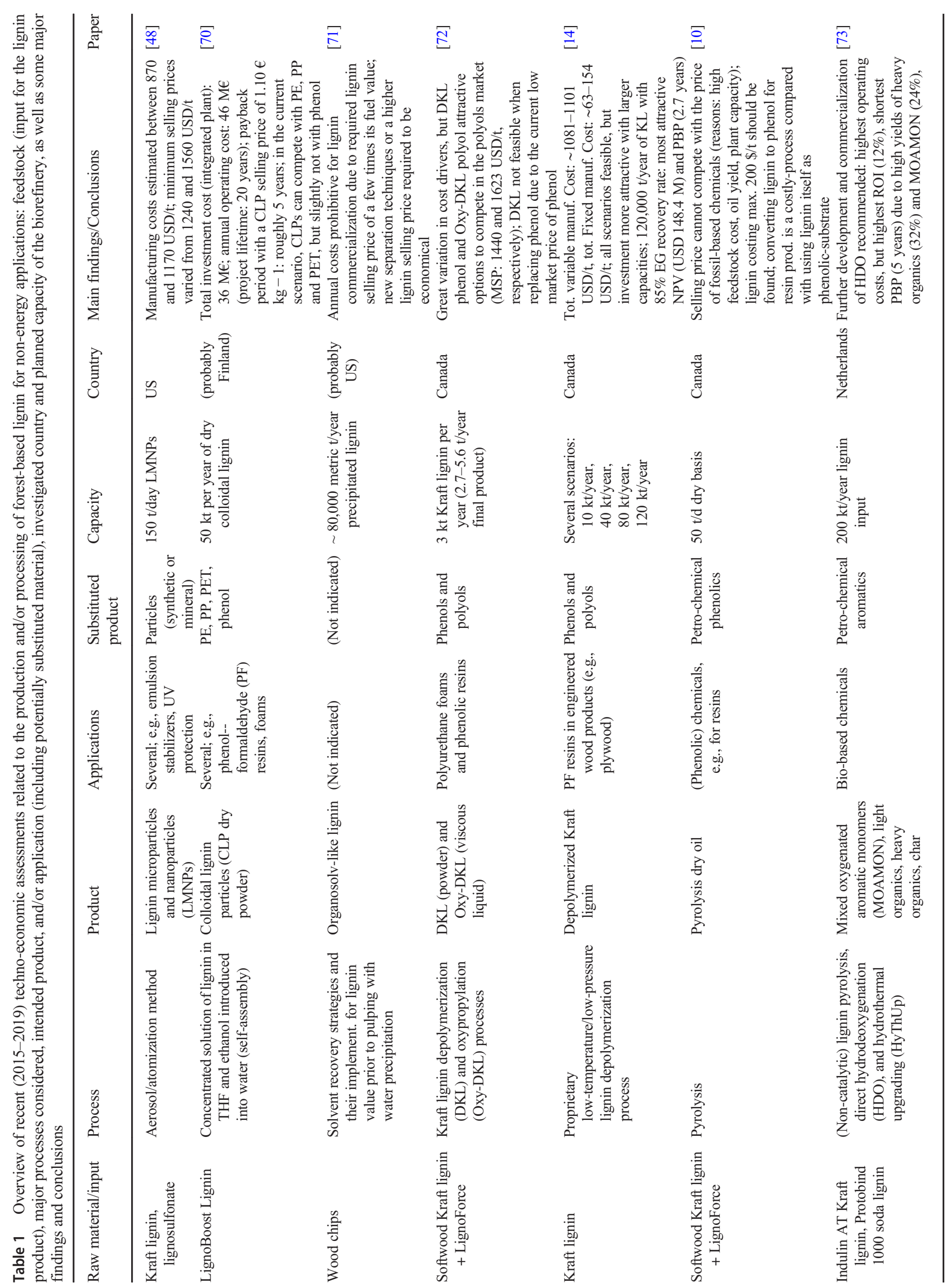




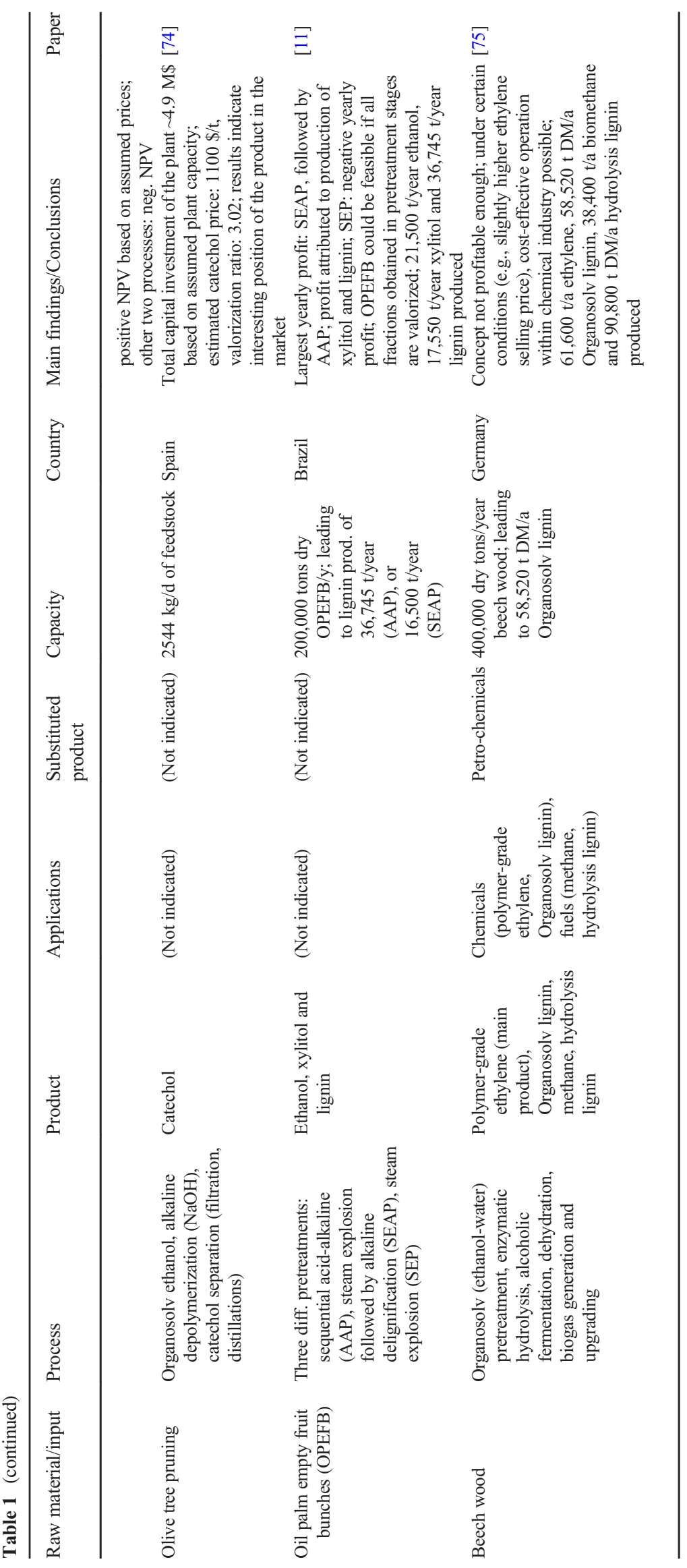




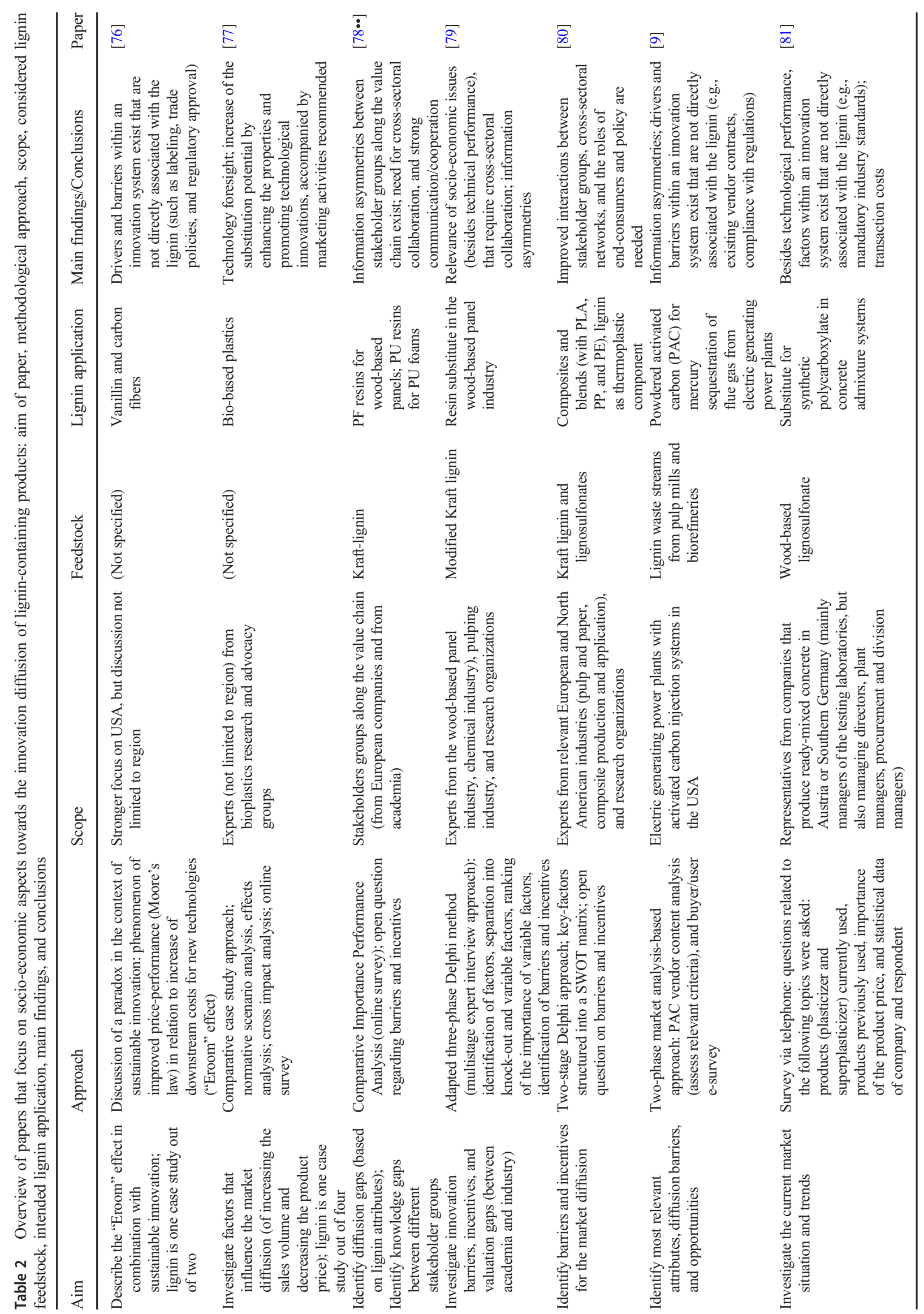




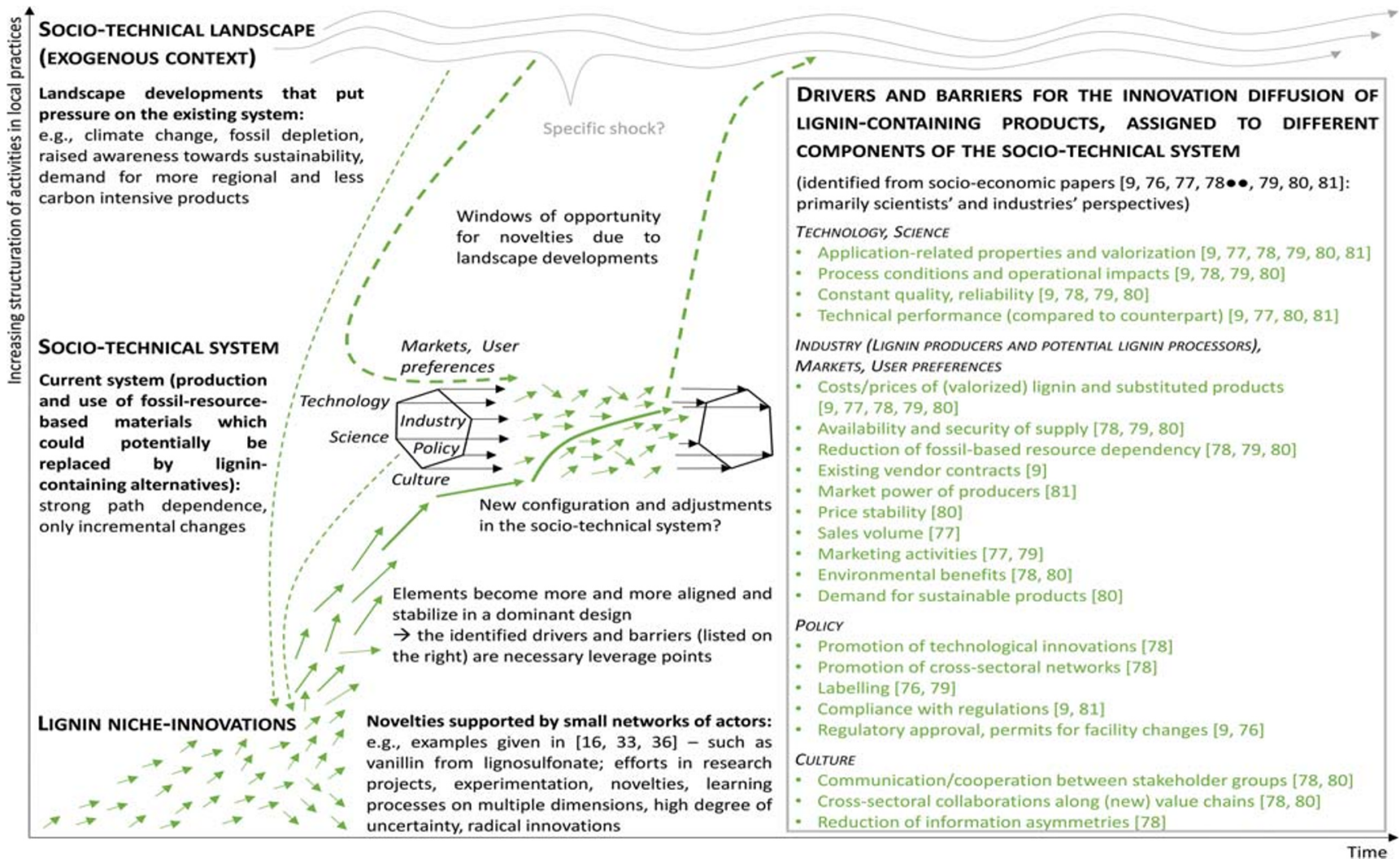

Fig. 3 Multi-level perspective towards transitions (adapted from [82] to the case of lignin) with drivers and barriers for the innovation diffusion of lignin-containing products (identified from papers in which research

polyurethane (PU) resins for PU foams by conducting an importance-performance analysis (IPA). The authors recommended reducing information asymmetries by cross-sectoral collaboration, improved communication, and new cooperation among stakeholders along the whole value chain [78••]. Stern et al. [79] investigated innovation barriers, incentives, and valuation gaps (between academia and industry) of modified Kraft lignin in the wood-based panel industry (partial replacement of fossil-based resins) using a multistage expert interview approach. Taking a similar, two-stage Delphi approach, Schmelzenbart et al. [80] identified barriers and incentives for the market diffusion of composites and blends (with PLA, PP, and PE) that contained Kraft lignin and lignosulfonates as thermoplastic components. To overcome bottlenecks, the creation of new value chains, the improvement of stakeholder interaction, the need for cross-sectoral networks, and the consideration of the role of end consumers and policy were mentioned as important factors [80]. Cline and Smith [9] applied a multi-phase, market-analysis-based approach to provide an exploratory market perspective on lignin-based powdered activated carbon (PAC) that could be injected into electric generating power plant flue gas to sequester mercury by adsorption. Earlier, Stern and Schwarzbauer [81] had investigated the current market situation and trends for wood-based lignosulfonate, comparing it with synthetic polycarboxylate in approaches are followed in the broader sense of innovation systems or cross-sector collaborations $[9,76,77,78 \bullet \bullet, 79-81]$ )

concrete admixture systems. They concluded that recent mandatory standards, weaker technological performance, and lower producer market power were responsible for a downward trend in the use of lignosulfonate-based plasticizers. With regard to switching costs, the authors found that price changes of around $14 \%$ encouraged the concrete industry to switch products [81].

The authors of seven papers that included results of socioeconomic assessments identified drivers for and barriers to the innovation diffusion of lignin-based products. These were identified as not only being related to technical aspects but also to other aspects that are relevant in the socio-technical system $[82,83]$. The drivers and barriers were collected, combined, and assigned to components of the socio-technical system [82] (Fig. 3). The multi-level perspective on transitions sometimes encourages the use of different definitions for the terms "system" and "regime"; in this paper, we use the term "system" as an umbrella term for both the tangible elements and the "underlying deep structures" [83]. The overview is not exhaustive but illustrates the drivers and barriers that have been identified thus far, contributing towards a broader system understanding. Table 2 summarizes the aims, approaches, and scopes of these papers, as well as the lignin feedstock and applications indicated. The main findings and conclusions, aside from the cost/price and technical requirements, are 
highlighted. These are related to relevant factors that are not directly associated with the lignin (e.g., labeling, trade policies, regulatory approval, vendor contracts, and industry standards), information asymmetries between stakeholder groups along the value chain, transaction costs, and the strong need for cross-sectoral collaborations and networks.

\section{Conclusions and Discussion}

The vision of efficient forest-based biorefineries will not become reality until lignin has been successfully commercialized [84-88]. This successful commercialization will have a major impact on wood prices and, thus, promote the profitability of forest management [3]. However, the large-scale, effective commercialization of lignin has not yet taken place [e.g., 16••]. Despite the fact that researchers have invested a reasonable amount of efforts over the last 30 years in investigating technology-related issues, such as the extraction, characterization, and application of technical lignin, the application of lignin is still limited to energy production and some niche applications [e.g., 17, 18, 85, 89]. At the same time, scientific publications refer to lignin as abundant [e.g., 17, 18, 85, 89] and underutilized [e.g., 5, 18, 19, 85]. From an innovation theory perspective, this indicates that the raw material availability is pushing the respective innovations forward (availability push), while the technical aspects have been perceived thus far as the major barrier to valorization [e.g., 5, 17-19, 85, 90]. Accordingly, recent literature reviews have mostly placed a focus on specific application fields, with authors taking rather technological viewpoints [e.g., 1, 8, 24, 40, $41,43,44]$. It may be argued that technology-related aspects, such as the proper characterization of technical lignin and an understanding of structure-property relationships, are needed before a valuation can be achieved. However, producible lignin qualities are highly variable, considering the different feedstocks, production processes, and modification and application options that are currently under investigation. Hence, it seems more efficient to consider technical aspects and valuation as iterative actions.

The literature addressing technical lignin from a sustainability or economic perspective can be divided into two different streams: TEA and LCA studies and socio-economic papers in which an innovation or market perspective is typically taken. While the TEAs and LCAs are generally based on data from technological research, and mainly cover production processes and their impacts, the latter refer to stakeholder interactions in research and development (R\&D) processes or on the markets.

The TEAs frequently identified the cost of the lignin feedstock $[10,14,48,70,72-75]$ and the achievable market price for the final product $[14,72-75]$ as the most sensitive input factors. The considerable cost of wood, as a major lignin feedstock in lignocellulose biorefineries, is dependent on allocation procedures [e.g., 68, 69] and may be influenced by lignin utilization in terms of an increased wood-paying capacity if competition for the resource increases [3]. The achievable market price for lignin-based products mainly depends on the chemical or material substituted which, in turn, depends on the final utilization path. However, in most cases, lignin targets the replacement of fossil-based feedstock; therefore, the crude oil prices serve as the primary reference. These study findings evoked the question of whether it is sufficient to earn money with technical lignin without considering sustainability-related aspects, such as the negative environmental externalities of crude oil. Technical lignin utilization requires the consideration of additional aspects, because it is part of a transition towards a circular bioeconomy in a coupled social-ecological system [91]. These aspects include an investigation of appropriate policies and instruments (e.g., economic incentives, carbon taxes), further research efforts (e.g., on sustainability issues, markets, technologies), and efficient resource planning $[92,93]$.

While cost-revenue considerations are clearly in line with what is considered as neo-classical economics (e.g., perfect markets, profit maximization), socio-economic perspectives based on modern economic theory need to be taken to create a more holistic understanding of the underlying innovation processes. Transaction costs, such as those incurred by ensuring the security of supply [79], switching costs [81], or information asymmetries [78••] also explain why the effective commercialization of lignin lags behind. Only seven papers were identified in our review that clearly contribute to this research stream in the lignin area. Most of these indicate that the regulatory or market pull is not (yet) a driver in the overall innovation process. Until now, lignin researchers have focused mainly on internal (direct) factors that influence the success of commercialization (e.g., improving technology, performance, reducing costs, optimizing processes) while paying little attention to external (indirect) factors (e.g., substitution markets, demands, regulatory issues). However, fostering a circular forest-based bioeconomy that is profitable, environmentally favorable, innovative, technically feasible, and socially desirable is a challenge [93]. Innovation tends to follow a nonlinear, iterative process that often involves numerous individuals and organizations (such as industry, academia, different levels of government, NGOs, and civil society) $[94,95]$. Therefore, more holistic approaches, such as the integration of internal and external factors by means of taking a systems approach [see, for instance, 96], need to be taken to move beyond the current focus on isolated and technological aspects of the bioeconomy transition pathways [91, 94].

Bauer et al. [94] reviewed the topic of innovation systems for biorefineries. They stated that the conditions for types of biorefinery products other than the predominant biofuels, and especially higher value products, are not yet well-understood, 
pointing out numerous gaps in the scientific literature. These gaps include the roles of policy strategies and instruments, consumer preferences, legitimacy, and social acceptance. In addition, the authors stated that case studies (both successful and unsuccessful cases) could help researchers to gain valuable insights into, e.g., the relevance of organizational trust and networks in biorefinery development [94]. It is necessary to collaborate in networks and form partnerships across sectors, as well as involve public and private actors, to include a greater variety of industries and products in biorefinery development $[94,97]$. With regard to the lignin research area, for instance, the perspectives of additional decision-makers (e.g., policy makers, consumers) could be of interest, as these have not yet been stressed in underlying studies on lignin. Researchers who applied a Delphi-study approach to survey European pulp and paper industry experts concluded that cross-sectoral partnerships will play a major role in developing new products in the European pulp and paper industry and predicted major changes in the future products [98]. Forest companies could benefit from cooperation with sectors that have a more positive demand outlook, including potential benefits such as increased competitiveness and environmental sustainability $[98,99]$. However, cross-sector collaboration still presents major challenges [99]. The importance of cultivating an open-minded organizational culture and supporting collaboration was emphasized by Näyhä and Pesonen [100], whereby the main barriers identified to transforming the forest industry towards the biorefining business were related to the conservative organizational culture and lack of financial resources.

Mastering global challenges, such as climate change, requires actors and stakeholders to make changes not only in the niches but also in the socio-technical system. Therefore, even if the lignin- and other biorefinery niche-innovations are successful, and changes at the landscape level place pressure on the current socio-technical system, windows of opportunity must be used to achieve breakthroughs on mainstream markets [82].

\footnotetext{
Acknowledgments We heartily thank our study assistants: Martin Popowicz for supporting us with the coding in MaxQDA and Julia Graf for her organizational help with the "statements with economic relevance" part. Many thanks also go to our colleagues Magdalena Rusch, Stefanie Hatzl, Eva Fleiß, and Arijit Paul for their constructive feedback and discussions on different aspects of the manuscript. We acknowledge our gratitude for support from the University of Graz. We gratefully acknowledge the industrial partners Sappi Austria Produktions-GmbH \& Co KG, Zellstoff Pöls AG, and Mondi Frantschach GmbH, and the Competence Centers for Excellent Technologies (COMET), promoted by BMVIT, BMDW, Styria, and Carinthia and managed by FFG, for their financial support of the K-project FLIPPR ${ }^{2}$ (Future Lignin and Pulp Processing Research-PROCESS INTEGRATION; FFG project number: 861476).
}

Funding Open access funding provided by University of Graz. Julia Wenger, Verena Haas, and Tobias Stern received funding through
FLIPPR $^{2}$ (Future Lignin and Pulp Processing Research-PROCESS INTEGRATION; FFG project number: 861476), which is financially supported by the industrial partners Sappi Austria Produktions-GmbH \& Co KG, Zellstoff Pöls AG, and Mondi Frantschach GmbH, and the Competence Centers for Excellent Technologies (COMET), promoted by BMVIT, BMDW, Styria and Carinthia, and managed by FFG. The University of Graz paid the open access publishing fee.

\section{Compliance with Ethical Standards}

Conflict of Interest Julia Wenger, Verena Haas, and Tobias Stern declare that they have no conflict of interest.

Human and Animal Rights and Informed Consent This article does not contain any studies with human or animal subjects performed by any of the authors.

Open Access This article is licensed under a Creative Commons Attribution 4.0 International License, which permits use, sharing, adaptation, distribution and reproduction in any medium or format, as long as you give appropriate credit to the original author(s) and the source, provide a link to the Creative Commons licence, and indicate if changes were made. The images or other third party material in this article are included in the article's Creative Commons licence, unless indicated otherwise in a credit line to the material. If material is not included in the article's Creative Commons licence and your intended use is not permitted by statutory regulation or exceeds the permitted use, you will need to obtain permission directly from the copyright holder. To view a copy of this licence, visit http://creativecommons.org/licenses/by/4.0/.

\section{References}

Papers of particular interest, published recently, have been highlighted as:

- Of importance

•. Of major importance

1. Li T, Takkellapati S. The current and emerging sources of technical lignins and their applications. Biofuels Bioprod Bioref. 2018;12(5):756-87. https://doi.org/10.1002/bbb.1913 The authors of this paper focused on the practical implementation of lignin, and provided a conclusive overview of technical lignin sources and main application areas (with a view to polymeric lignin and depolymerized lignin).

2. Wenger J, Stern T. Reflection on the research on and implementation of biorefinery systems - a systematic literature review with a focus on feedstock. Biofuels Bioprod Bioref. 2019;13(5):134764. https://doi.org/10.1002/bbb.2021.

3. Stern T, Ledl C, Braun M, Hesser F, Schwarzbauer P. Biorefineries' impacts on the Austrian forest sector: a system dynamics approach. Technol Forecast Soc Chang. 2015;91:311-26. https://doi.org/10.1016/j.techfore.2014.04.001.

4. Galkin MV, Samec JS. Lignin valorization through catalytic lignocellulose fractionation: a fundamental platform for the future biorefinery. ChemSusChem. 2016;9(13):1544-58. https://doi. org/10.1002/cssc. 201600237.

5. Michels J, Wagemann K. The German lignocellulose feedstock biorefinery project. Biofuels Bioprod Bioref. 2010;4(3):263-7. https://doi.org/10.1002/bbb.216. 
6. Pettersen RC. The chemical composition of wood. In: Rowell RM, editor. The Chemistry of Solid Wood. Washington, DC: American Chemical Society; 1984. p. 57-126.

7. Hellsmark H, Söderholm P. Innovation policies for advanced biorefinery development: key considerations and lessons from Sweden. Biofuels Bioprod Bioref. 2017;11(1):28-40. https://doi. org/10.1002/bbb.1732.

8. Collins MN, Nechifor M, Tanasă F, Zănoagă M, McLoughlin A, Stróżyk MA, et al. Valorization of lignin in polymer and composite systems for advanced engineering applications - a review. Int J Biol Macromol. 2019;131:828-49. https://doi.org/10.1016/j. ijbiomac.2019.03.069.

9. Cline SP, Smith PM. Opportunities for lignin valorization: an exploratory process. Energy Sustain Soc. 2017;7(1). https://doi. org/10.1186/s13705-017-0129-9.

10. Farag S, Chaouki J. Economics evaluation for on-site pyrolysis of Kraft lignin to value-added chemicals. Bioresour Technol. 2015;175:254-61. https://doi.org/10.1016/j.biortech.2014.10. 096.

11. Coral Medina JD, Woiciechowski AL, Filho AZ, Brar SK, Magalhães Júnior AI, Soccol CR. Energetic and economic analysis of ethanol, xylitol and lignin production using oil palm empty fruit bunches from a Brazilian factory. J Clean Prod. 2018;195: 44-55. https://doi.org/10.1016/j.jclepro.2018.05.189.

12. Isikgor FH, Becer CR. Lignocellulosic biomass: a sustainable platform for the production of bio-based chemicals and polymers. Polym Chem. 2015;6(25):4497-559. https://doi.org/10.1039/ c5py00263j.

13. Holladay JE, White JF, Bozell JJ, Johnson D. Top value added chemicals from biomass, volume II: results of screening for potential candidates from biorefinery lignin. PNNL-16983. PNNL, NREL and DOE; 2007.

14. Dessbesell L, Yuan Z, Leitch M, Paleologou M, Pulkki R, Xu CC. Capacity design of a kraft lignin biorefinery for production of biophenol via a proprietary low-temperature/low-pressure lignin depolymerization process. ACS Sustain Chem Eng. 2018;6(7): 9293-303. https://doi.org/10.1021/acssuschemeng.8b01582.

15. Van Heiningen A. Converting a Kraft pulp mill into an integrated forest biorefinery. Pulp Pap Can. 2006;107(6):38-43.

16.•• Dessbesell L, Paleologou M, Leitch M, Pulkki R, Xu CC. Global lignin supply overview and Kraft lignin potential as an alternative for petroleum-based polymers. Renew Sust Energ Rev. 2020;123. https://doi.org/10.1016/j.rser.2020.109768 This paper contains the most recent and detailed overview of the global lignin market and supply, in particular with a view to Kraft-lignin based phenols and polyols.

17. Lora JH, Glasser WG. Recent industrial applications of lignin: a sustainable alternative to nonrenewable materials. J Polym Environ. 2002;10(1-2):39-48. https://doi.org/10.1023/A: 1021070006895.

18. Ragauskas AJ, Beckham GT, Biddy MJ, Chandra R, Chen F, Davis MF, et al. Lignin valorization: Improving lignin processing in the biorefinery. Science. 2014;344(6185). https://doi.org/10. 1126/science. 1246843 .

19. Stewart D. Lignin as a base material for materials applications: chemistry, application and economics. Ind Crop Prod. 2008;27(2): 202-7. https://doi.org/10.1016/j.indcrop.2007.07.008.

20. Abejón R, Pérez-Acebo H, Clavijo L. Alternatives for chemical and biochemical lignin valorization: hot topics from a bibliometric analysis of the research published during the 2000-2016 period. Process. 2018;6(8). https://doi.org/10.3390/pr6080098.

21. Kai D, Tan MJ, Chee PL, Chua YK, Yap YL, Loh XJ. Towards lignin-based functional materials in a sustainable world. Green Chem. 2016;18(5):1175-200. https://doi.org/10.1039/ c5gc02616d.
22. Hodásová L, Jablonský M, Škulcová A, Ház A. Lignin, potential products and their market value. Wood Res. 2015;60(6):973-86.

23. Wang H, Pu Y, Ragauskas A, Yang B. From lignin to valuable products-strategies, challenges, and prospects. Bioresour Technol. 2019;271:449-61. https://doi.org/10.1016/j.biortech. 2018.09.072.

24. Gil-Chávez J, Gurikov P, Hu X, Meyer R, Reynolds W, Smirnova I. Application of novel and technical lignins in food and pharmaceutical industries: structure-function relationship and current challenges. Biomass Convers Biorefin. 2019. https://doi.org/10. 1007/s13399-019-00458-6.

25. Sipponen MH, Lange H, Crestini C, Henn A, Österberg M. Lignin for nano- and microscaled carrier systems: applications, trends, and challenges. ChemSusChem. 2019;12(10):2039-54. https:// doi.org/10.1002/cssc.201900480.

26. Rinaldi R, Jastrzebski R, Clough MT, Ralph J, Kennema M, Bruijnincx PCA, et al. Paving the way for lignin valorisation: recent advances in bioengineering, biorefining and catalysis. Angew Chem Int Ed. 2016;55(29):8164-215. https://doi.org/10. 1002/anie.201510351.

27. Becker J, Wittmann C. A field of dreams: lignin valorization into chemicals, materials, fuels, and health-care products. Biotechnol Adv. 2019;37:37(6). https://doi.org/10.1016/j.biotechadv.2019. 02.016 .

28. Cao Y, Chen SS, Zhang S, Ok YS, Matsagar BM, Wu KC, et al. Advances in lignin valorization towards bio-based chemicals and fuels: lignin biorefinery. Bioresour Technol. 2019;291:291. https://doi.org/10.1016/j.biortech.2019.121878.

29. Mei Q, Shen X, Liu H, Han B. Selectively transform lignin into value-added chemicals. Chin Chem Lett. 2019;30(1):15-24. https://doi.org/10.1016/j.cclet.2018.04.032.

30. Rutten C, Ramírez A, Posada DJ. Hydrotreating and hydrothermal treatment of alkaline lignin as technological valorization options for future biorefinery concepts: a review. J Chem Technol Biotechnol. 2017;92(2):257-70. https://doi.org/10.1002/jctb. 5103.

31. Kamimura N, Sakamoto S, Mitsuda N, Masai E, Kajita S. Advances in microbial lignin degradation and its applications. Curr Opin Biotechnol. 2019;56:179-86. https://doi.org/10.1016/ j.copbio.2018.11.011.

32. Lee S, Kang M, Bae J, Sohn J, Sung BH. Bacterial valorization of lignin: strains, enzymes, conversion pathways, biosensors, and perspectives. Front Bioeng Biotechnol. 2019;7. https://doi.org/ 10.3389/fbioe.2019.00209.

33. Li C, Chen C, Wu X, Tsang C, Mou J, Yan J, et al. Recent advancement in lignin biorefinery: with special focus on enzymatic degradation and valorization. Bioresour Technol. 2019;291: 121898. https://doi.org/10.1016/j.biortech.2019.121898.

34. Li X, Zheng Y. Biotransformation of lignin: mechanisms, applications and future work. Biotechnol Prog. 2020;36:36(1). https:// doi.org/10.1002/btpr.2922.

35. Xu Z, Lei $\mathrm{P}$, Zhai R, Wen Z, Jin M. Recent advances in lignin valorization with bacterial cultures: microorganisms, metabolic pathways, and bio-products. Biotechnol Biofuels. 2019:12(1). https://doi.org/10.1186/s13068-019-1376-0.

36. Bajwa DS, Pourhashem G, Ullah AH, Bajwa SG. A concise review of current lignin production, applications, products and their environment impact. Ind Crop Prod. 2019;139. https://doi.org/10. 1016/j.indcrop.2019.111526 In this paper, a concise overview of current lignin production and its applications is provided, including a small review on lignin-related LCA and TEA papers.

37. Roopan SM. An overview of natural renewable bio-polymer lignin towards nano and biotechnological applications. Int J Biol Macromol. 2017;103:508-14. https://doi.org/10.1016/j.ijbiomac. 2017.05.103. 
38. Tsvetkov MV, Salganskii EA. Lignin: applications and ways of utilization (review). Russ J Appl Chem. 2018;91(7):1129-36. https://doi.org/10.1134/S1070427218070108.

39. Aro T, Fatehi P. Production and application of lignosulfonates and sulfonated lignin. ChemSusChem. 2017;10(9):1861-77. https:// doi.org/10.1002/cssc.201700082.

40. Upton BM, Kasko AM. Strategies for the conversion of lignin to high-value polymeric materials: review and perspective. Chem Rev. 2016;116(4):2275-306. https://doi.org/10.1021/acs. chemrev.5b00345.

41. Rajesh Banu J, Kavitha S, Yukesh Kannah R, Poornima Devi T, Gunasekaran M, Kim S, et al. A review on biopolymer production via lignin valorization. Bioresour Technol. 2019;290:121790. https://doi.org/10.1016/j.biortech.2019.121790.

42. Tran MH, Lee EY. Green preparation of bioplastics based on degradation and chemical modification of lignin residue. J Wood Chem Technol. 2018;38(6):460-78. https://doi.org/10.1080/ 02773813.2018.1533978.

43. Beisl S, Friedl A, Miltner A. Lignin from micro- to nanosize: applications. Int J Mol Sci. 2017;18(11). https://doi.org/10.3390/ ijms 18112367.

44. Espinoza-Acosta JL, Torres-Chávez PI, Olmedo-Martínez JL, Vega-Rios A, Flores-Gallardo S, Zaragoza-Contreras EA. Lignin in storage and renewable energy applications: a review. J Energy Chem. 2018;27(5):1422-38. https://doi.org/10.1016/j.jechem. 2018.02.015.

45. Spiridon I. Biological and pharmaceutical applications of lignin and its derivatives: a mini-review. Cellul Chem Technol. 2018;52(7-8):543-50.

46. Graichen FHM, Grigsby WJ, Hill SJ, Raymond LG, Sanglard M, Smith DA, et al. Yes, we can make money out of lignin and other bio-based resources. Ind Crop Prod. 2017;106:74-85. https://doi. org/10.1016/j.indcrop.2016.10.036.

47. Gabriel M, Schöggl J, Posch A. Early front-end innovation decisions for self-organized industrial symbiosis dynamics - a case study on lignin utilization. Sustainability. 2017;9(4). https://doi. org/10.3390/su9040515.

48. Abbati De Assis C, Greca LG, Ago M, Balakshin MY, Jameel H, Gonzalez R, et al. Techno-economic assessment, scalability, and applications of aerosol lignin micro- and nanoparticles. ACS Sustain Chem Eng. 2018;6(9):11853-68. https://doi.org/10. 1021/acssuschemeng.8b02151.

49. Obydenkova SV, Kouris PD, Hensen EJM, Smeulders DMJ, van der Meer Y, Boot MD. Industrial lignin from 2G biorefineriesassessment of availability and pricing strategies. Bioresour Technol. 2019;291. https://doi.org/10.1016/j.biortech.2019. 121805 Although this paper is not on forest-based lignin, the authors of this paper address a very sensitive and therefore important factor for lignin utilization in general: the issue of lignin pricing and pricing strategies.

50. Shen R, Tao L, Yang B. Techno-economic analysis of jet-fuel production from biorefinery waste lignin. Biofuels Bioprod Bioref. 2019;13(3):486-501. https://doi.org/10.1002/bbb.1952.

51. Bbosa D, Mba-Wright M, Brown RC. More than ethanol: a techno-economic analysis of a corn stover-ethanol biorefinery integrated with a hydrothermal liquefaction process to convert lignin into biochemicals. Biofuels Bioprod Bioref. 2018;12(3):497-509. https://doi.org/10.1002/bbb.1866.

52. Carvajal JC, Gómez Á, Cardona CA. Comparison of lignin extraction processes: economic and environmental assessment. Bioresour Technol. 2016;214:468-76. https://doi.org/10.1016/j. biortech.2016.04.103.

53. Han J. Process design and techno-economic evaluation for catalytic production of cellulosic $\gamma$-Valerolactone using lignin derived propyl guaiacol. J Ind Eng Chem. 2017;52:218-23. https://doi. org/10.1016/j.jiec.2017.03.048.
54. Martinez-Hernandez E, Cui X, Scown CD, Amezcua-Allieri MA, Aburto J, Simmons BA. Techno-economic and greenhouse gas analyses of lignin valorization to eugenol and phenolic products in integrated ethanol biorefineries. Biofuels Bioprod Bioref. 2019;13(4):978-93. https://doi.org/10.1002/bbb.1989.

55. Schmidt LM, Pérez Martínez V, Kaltschmitt M. Solvent-free lignin recovered by thermal-enzymatic treatment using fixed-bed reactor technology - economic assessment. Bioresour Technol. 2018;268:382-92. https://doi.org/10.1016/j.biortech.2018.07. 107.

56. Pierobon F, Eastin IL, Ganguly I. Life cycle assessment of residual lignocellulosic biomass-based jet fuel with activated carbon and lignosulfonate as co-products. Biotechnol Biofuels. 2018;11(1). https://doi.org/10.1186/s13068-018-1141-9.

57. Ge Y, Dababneh F, Li L. Economic evaluation of lignocellulosic biofuel manufacturing considering integrated lignin waste conversion to hydrocarbon fuels. Procedia Manuf. 2017;10:112-22. https://doi.org/10.1016/j.promfg.2017.07.037.

58. Obydenkova SV, Kouris PD, Hensen EJM, Heeres HJ, Boot MD. Environmental economics of lignin derived transport fuels. Bioresour Technol. 2017;243:589-99. https://doi.org/10.1016/j. biortech.2017.06.157.

59. Lettner M, Solt P, Rößiger B, Pufky-Heinrich D, Jääskeläinen A, Schwarzbauer $\mathrm{P}$, et al. From wood to resin-identifying sustainability levers through hotspotting lignin valorisation pathways. Sustainability. 2018;10(8). https://doi.org/10.3390/su10082745.

60. Montazeri M, Eckelman MJ. Life cycle assessment of catechols from lignin depolymerization. ACS Sustain Chem Eng. 2016;4(3):708-18. https://doi.org/10.1021/acssuschemeng. $5 \mathrm{~b} 00550$

61. Culbertson C, Treasure T, Venditti R, Jameel H, Gonzalez R. Life cycle assessment of lignin extraction in a softwood Kraft pulp mill. Nordic Pulp Pap Res. 2016;31(1):30-40.

62. Yuan Y, Guo M. Do green wooden composites using lignin-based binder have environmentally benign alternatives? A preliminary LCA case study in China. Int J Life Cycle Assess. 2017;22(8): 1318-26. https://doi.org/10.1007/s11367-016-1235-1.

63. Isola C, Sieverding HL, Numan-Al-Mobin AM, Rajappagowda R, Boakye EA, Raynie DE, et al. Vanillin derived from lignin liquefaction: a sustainability evaluation. Int J Life Cycle Assess. 2018;23(9):1761-72. https://doi.org/10.1007/s11367-017-14010 .

64. Secchi M, Castellani V, Orlandi M, Collina E. Use of lignin sidestreams from biorefineries as fuel or co-product? Life cycle analysis of bio-ethanol and pulp production processes. BioResources. 2019;14(2):4832-65.

65. Hildebrandt J, Budzinski M, Nitzsche R, Weber A, Krombholz A, Thrän D, et al. Assessing the technical and environmental performance of wood-based fiber laminates with lignin based phenolic resin systems. Resour Conserv Recycl. 2019;141:455-64. https:// doi.org/10.1016/j.resconrec.2018.10.029.

66. Hermansson F, Janssen M, Svanström M. Prospective study of lignin-based and recycled carbon fibers in composites through meta-analysis of life cycle assessments. J Clean Prod. 2019;223: 946-56. https://doi.org/10.1016/j.jclepro.2019.03.022.

67. Asada R, Cardellini G, Mair-Bauernfeind C, Wenger J, Haas V, Holzer D, et al. Effective bioeconomy? A MRIO-based socioeconomic and environmental impact assessment of generic sectoral innovations. Technol Forecast Soc Chang. 2020;153:119946. https://doi.org/10.1016/j.techfore.2020.119946.

68. Cherubini F, Strømman AH, Ulgiati S. Influence of allocation methods on the environmental performance of biorefinery products - a case study. Resour Conserv Recycl. 2011;55(11): 1070-7. https://doi.org/10.1016/j.resconrec.2011.06.001.

69. Sandin G, Røyne F, Berlin J, Peters GM, Svanström M. Allocation in LCAs of biorefinery products: implications for results and 
decision-making. J Clean Prod. 2015;93:213-21. https://oi.org/ 10.1016/j.jclepro.2015.01.013.

70. Bangalore Ashok RP, Oinas P, Lintinen K, Sarwar G, Kostiainen MA, Österberg M. Techno-economic assessment for the largescale production of colloidal lignin particles. Green Chem. 2018;20(21):4911-9. https://doi.org/10.1039/c8gc02805b.

71. Chrisandina NJ, Kwok TT, Bommarius AS, Realff MJ. Technoeconomic analysis of water precipitation for lignin value prior to pulping. Chem Eng Res Des. 2019;143:4-10. https://doi.org/10. 1016/j.cherd.2018.10.042.

72. Dessbesell L, Yuan Z, Hamilton S, Leitch M, Pulkki R, Xu CC. Bio-based polymers production in a Kraft lignin biorefinery: techno-economic assessment. Biofuels Bioprod Bioref. 2018;12(2):239-50. https://doi.org/10.1002/bbb.1834.

73. Vural Gursel I, Dijkstra JW, Huijgen WJJ, Ramirez A. Technoeconomic comparative assessment of novel lignin depolymerization routes to bio-based aromatics. Biofuels Bioprod Bioref. 2019;13(4):1068-84. https://doi.org/10.1002/bbb.1999.

74. Mabrouk A, Erdocia X, Alriols MG, Labidi J. Economic analysis of a biorefinery process for catechol production from lignin. J Clean Prod. 2018;198:133-42. https://doi.org/10.1016/j.jclepro. 2018.06.294.

75. Nitzsche R, Budzinski M, Gröngröft A. Techno-economic assessment of a wood-based biorefinery concept for the production of polymer-grade ethylene, organosolv lignin and fuel. Bioresour Technol. 2016;200:928-39. https://doi.org/10.1016/j.biortech. 2015.11.008.

76. Hall J, Matos S, Gold S, Severino LS. The paradox of sustainable innovation: the 'Eroom' effect (Moore's law backwards). J Clean Prod. 2018;172:3487-97. https://doi.org/10.1016/j.jclepro.2017. 07.162.

77. Lettner M, Schöggl J, Stern T. Factors influencing the market diffusion of bio-based plastics: results of four comparative scenario analyses. J Clean Prod. 2017;157:289-98. https://doi.org/10. 1016/j.jclepro.2017.04.077.

78.•• Lettner M, Hesser F, Hedeler B, Schwarzbauer P, Stern T. Barriers and incentives for the use of lignin-based resins: results of a comparative importance performance analysis. J Clean Prod. 2020;256. https://doi.org/10.1016/j.jclepro.2020.120520 The authors of this paper identified diffusion gaps and knowledge gaps (information asymmetries) between different stakeholder groups regarding relevant attributes for ligninbased resins, and therewith demonstrated the need for crosssectoral collaborations.

79. Stern T, Heil G, Ledl C, Schwarzbauer P. Identifying innovation barriers using a Delphi method approach: the case of technical lignin in the wood-based panel industry. Internatl Wood Prod J. 2012;3(2):116-23. https://doi.org/10.1179/2042645312Y. 0000000015 .

80. Schmelzenbart AC, Lettner M, Hesser F, Schwarzbauer P. Barriers and incentives on the market diffusion of lignin composites: a Delphi-SWOT analysis. Pro Ligno. 2018;14(4):73-81.

81. Stern T, Schwarzbauer P. Wood-based lignosulfonate versus synthetic polycarboxylate in concrete admixture systems: the perspective of a traditional pulping by-product competing with an oilbased substitute in a business-to-business market in central Europe. For Prod J. 2008;58(1-2):81-6.

82. Geels FW, Schot J. Typology of sociotechnical transition pathways. Res Policy. 2007;36(3):399-417. https://doi.org/10.1016/j. respol.2007.01.003.

83. Geels FW. The multi-level perspective on sustainability transitions: responses to seven criticisms. Environ Innov Soc Trans. 2011;1(1):24-40. https://doi.org/10.1016/j.eist.2011.02.002.

84. Li C, Zhao X, Wang A, Huber GW, Zhang T. Catalytic transformation of lignin for the production of chemicals and fuels. Chem
Rev. 2015;115(21):11559-624. https://doi.org/10.1021/acs. chemrev.5b00155.

85. Vishtal A, Kraslawski A. Challenges in industrial applications of technical lignins. BioResources. 2011;6(3):3547-68.

86. Ragnar M, Henriksson G, Lindström ME, Wimby M, Blechschmidt J, Heinemann S. Pulp. In: Elvers B, Hawkins S, Harrer R, Kirsch-Pietz N, Pikart-Müller M, Rohn M, editors. Ullmann's encyclopedia of industrial chemistry. Weinheim: Wiley-VCH Verlag GmbH \& Co.; 2014. p. 15.

87. Liu W, Jiang $\mathrm{H}, \mathrm{Yu} \mathrm{H}$. Thermochemical conversion of lignin to functional materials: a review and future directions. Green Chem. 2015;17(11):4888-907. https://doi.org/10.1039/c5gc01054c.

88. Zhao W, Simmons B, Singh S, Ragauskas A, Cheng G. From lignin association to nano-/micro-particle preparation: extracting higher value of lignin. Green Chem. 2016;18(21):5693-700. https://doi.org/10.1039/c6gc01813k.

89. Gosselink RJA, De Jong E, Guran B, Abächerli A. Co-ordination network for lignin - standardisation, production and applications adapted to market requirements (EUROLIGNIN). Ind Crop Prod. 2004;20(2):121-9. https://doi.org/10.1016/j.indcrop.2004.04.015.

90. Kamm B, Gruber PR, Kamm M. Biorefineries: industrial processes and products. In: Elvers B, Hawkins S, Harrer R, Kirsch-Pietz N, Pikart-Müller M, Rohn M, editors. Ullmann's Encyclopedia of Industrial Chemistry. Weinheim: Wiley-VCH Verlag GmbH \& Co.; 2016. p. 38.

91. Bennich T, Belyazid S, Kopainsky B, Diemer A. The bio-based economy: Dynamics governing transition pathways in the Swedish forestry sector. Sustainability. 2018;10(4). https://doi. org/10.3390/su10040976.

92. Staffas L, Gustavsson M, McCormick K. Strategies and policies for the bioeconomy and bio-based economy: an analysis of official national approaches. Sustainability. 2013;5(6):2751-69. https:// doi.org/10.3390/su5062751.

93. Langeveld JWA, Dixon J, Jaworski JF. Development perspectives of the biobased economy: a review. Crop Sci. 2010;50:S-142-51. https://doi.org/10.2135/cropsci2009.09.0529.

94. Bauer F, Coenen L, Hansen T, McCormick K, Palgan YV. Technological innovation systems for biorefineries: a review of the literature. Biofuels Bioprod Bioref. 2017;11(3):534-48. https://doi.org/10.1002/bbb.1767.

95. Leavengood S, Bull L. Innovation in the global forest sector. In: Hansen E, Panwar R, Vlosky R, editors. The Global Forest Sector: Changes, Practices, and Prospects. Boca Raton: CRC Press; 2013. p. 377-404. https://doi.org/10.1201/b16186.

96. Kiesling E, Günther M, Stummer C, Wakolbinger LM. Agentbased simulation of innovation diffusion: a review. CEJOR. 2012;20(2):183-230. https://doi.org/10.1007/s10100-011-0210y.

97. Bryson JM, Crosby BC, Stone MM. Designing and implementing cross-sector collaborations: needed and challenging. Public Adm Rev. 2015;75(5):647-63. https://doi.org/10.1111/puar.12432.

98. Toppinen A, Pätäri S, Tuppura A, Jantunen A. The European pulp and paper industry in transition to a bio-economy: a Delphi study. Futures. 2017;88:1-14. https://doi.org/10.1016/j.futures.2017.02. 002.

99. Guerrero JE, Hansen E. Cross-sector collaboration in the forest products industry: a review of the literature. Can J For Res. 2018;48(11):1269-78. https://doi.org/10.1139/cjfr-2018-0032.

100. Näyhä A, Pesonen H. Strategic change in the forest industry towards the biorefining business. Technol Forecast Soc Chang. 2014;81(1):259-71. https://doi.org/10.1016/j.techfore.2013.04. 014.

Publisher's Note Springer Nature remains neutral with regard to jurisdictional claims in published maps and institutional affiliations. 